\title{
Evaluation of Elemental Sulphur Application with Rhizobia Inoculation on Peanut Yield and its Quality Grown in Sandy Soil at Egypt
}

T. E.E. Radwan ${ }^{* 1}$, Hanaa H. Rafla** ${ }^{*}$ and R. N. Zaki***

*Botany Dept., Faculty of Science, Fayoum University, Fayoum, Plant Nutrition Dept., Soils, Water and Environ. Res. Inst., ARC, Giza and ${ }^{* * *}$ Agric. Microbiol. Dept., Soils, Water and Environ. Res. Inst., ARC, Giza, Egypt.

\begin{abstract}
7 WO field experiments were conducted during the summer of two successive seasons of 2011 and 2012, to identify the response of peanut (Arachis hypogaea L., cv. Giza 5) to soil application of elemental sulphur (at rate of 15, 30 and $45 \mathrm{Kg} / \mathrm{fed}$ before sowing) and Rhizobia (Bradyrhizobium japonicum) inoculation, individually or in combination, for determination of the yield criteria, pods yield, 100 seeds yield, seeds \& straw yield and shilling percentage at harvest, as well as seed oil, oil yield, protein content and protein yield. The associated amelioration in plant macro and micronutrient contents and uptake, and soil biological activities (nodulation status, nitrogenase, dehydrogenase, $\mathrm{CO}_{2}$ evolution and total bacterial counts) were assessed in this study. The obtained results indicated that Rhizobium inoculation or $\mathrm{S}$ addition alleviated the adverse effect of soil nutrient deficiency and caused significant increases in all the studied parameters of peanut and soil. Rhizobium inoculation individually caused insignificant increases in all the studied parameters over $\mathrm{S}$ addition solely at $45 \mathrm{~kg}$ s/fed. Joint addition of sulphur at all rates with Rhizobium inoculation, gave high significant increases in all prior studied parameters and soil biological parameters at 50 and 80 days after peanut sowing followed by the individual treatments.
\end{abstract}

Keywords: Peanut, Sulphur, Rhizobium inoculation, Biological activity of soil and sandy soil.

Peanut, (Arachis hypogaea L.) is one of the most important crops in Egypt for both exportation and locally consumption. Due to its high nutritive value, peanut seeds are used as a source of dietary protein $(25-30 \%)$, oil production for industrial purposes (more than $40 \%$ ), human consumption and animal feeding. Also, it improves soil properties by increasing organic matter and nitrogen content (Khalifa et al., 2013). Increasing peanut production for local consumption and export abroad could be achieved by cultural practices and management as well as chosen the proper planting (Abd El-Maksoud, 2008).

\footnotetext{
${ }^{1}$ Corresponding author: e-mail: tsd00@ fayoum.edu.eg
} 
Biotic and abiotic fertilization were of great importance for increasing peanut quality and productivity.

Sulphur is one of the most macronutrients for the plant, so it plays an important role in growth and development of plants being a constituent of three amino acids viz., methionine, cysteine and cystine. Sulphur is also needed for the synthesis of other metabolites like co-enzyme A, biotin, thiamin (Vitamin B1) and glutathione, besides its role in the synthesis of chlorophyll and improves nodulation in legumes. Due to continuous use of high grade of $\mathrm{S}$ free fertilizers and intensive cropping, its deficiency has been reported as hidden hunger in many crops, especially pulses. Ahmad and Abdin (2000) demonstrated that high $\mathrm{S}$ fertilization increases chlorophyll, and protein contents in fully expanded upper leaves of Brassica juncea L. (mustard) and Brassica campestris L., which implies a better photosynthetic activity in comparison with plants grown without sulphur.

Sulphur is usually required by legumes for protein synthesis as a constituent of three amino acids; cystein, cystine and methionine (ELSaadany and Abd EL_Rasoul, 1999), contributes in the conformation of enzyme protein and some coenzyme A essential for metabolism (Nassar et al., 2006), promotes reproductive development and nitrogen fixation and is called a master nutrient for oil seed production (El-Hamzawi, 2000). Sulphur also increases sugar content of seed (El-Sayed, 2006) and favorable increases translocation of carbohydrates through hydrolyzing more glycosides (Azer et al., 2003). The botanical requirement for sulfur equals or exceeds the requirement for phosphorus. It is an essential nutrient for plant growth, root nodule formation of legumes, and immunity and defense systems. Sulfur deficiency has become widespread in many countries (Ceccotti, 1996; Zhao et al., 1999 and BlakeKalff, 2000).

Use of Microorganisms as biotic fertilizer, which can either fix atmospheric nitrogen, solubilize phosphate, synthesis of growth promoting substances or by enhancing the decomposition of plant residues to release vital nutrients and increase humic content of soil, will be environmentally begin approach for nutrient management and ecosystem function (Wu et al., 2005). Of the wellknown biofertilizeres are the microbial inoculants, which applied to seeds or soil in order to increase soil fertility and plant growth. Zahran (1999) reported that, biological Nitrogen fixation represent the major source of $\mathrm{N}$ input in agricultural soils including those of arid regions. The major $\mathrm{N}$-fixing systems are the symbiotic systems, which play a significant role in improving soil fertility and productivity of low $\mathrm{N}$-soils.

The Rhizobium-legume symbioses have received most attention and have been examined extensively. Atta et al. (2003) and Mohsen and Saeed (2005) reported that, Rhizobium inoculation significantly increased number of pods/plant, seed number/pod, seeds weight/pod, seeds weight/plant, 100-seed weight as well as seed and straw yield, N, P, K, Mn and Zn uptake of legume Egypt. J. Bot. 57, No.1 (2017) 
plants. These microorganisms, especially those associated with roots, have the ability to increase plant growth and productivity (Kloepper, 2003). In a few cases, this effect has been suggested to involve solubilization of otherwise unavailable mineral nutrients (Badawi et al., 2011). In soil, both macro- and micronutrients undergo a complex dynamic equilibrium of solubilization and insolubilization that is greatly influenced by the soil $\mathrm{pH}$ and microflora and that ultimately affects their accessibility to plant roots for absorption (Kandil et al., 2008). Rhizobia are widely used in agriculture for crop improvement because of their ability to fix atmospheric nitrogen. Inoculation of legumes with many selective rhizobia lead to increments in seed yield and nitrogen content (Mekhemar et al., 2005).

This investigation was carried out to identify the response of peanut (Arachis hypogaea L, cv. Giza 5) to sulphur fertilization at rate of $(15,30$ and $45 \mathrm{Kg} / \mathrm{fed}$ before sowing) and Rhizobia (Bradyrhizobium japonicum) inoculation, individually or in combination, under sandy soil conditions for determination of the yield criteria, pods yield, 100 seeds yield, seeds \& straw yield and shilling percentage at harvest, as well as seed oil, oil yield, protein content and protein yield. The associated amelioration in plant macro and micronutrient contents and uptake, nodulation status (number and dry weight of nodules/plant), nitrogenase, dehydrogenase, $\mathrm{CO}_{2}$ evolution and total bacterial counts were taking into consideration in this study. By which enable the peanut to tolerate nutrient deficiency and survive, not only by completing its life cycle, but also, by appropriating to be marketing.

\section{Material and Methods}

\section{Layout of experimental field}

A field experiment was carried out in sandy soil at Ismailia Agricultural Research Station, Ismailia Governorate, Egypt, during the two successive seasons of 2011 and 2012, to identify the response of peanut (Arachis hypogaea L, cv. Giza 5) to sulphur and Rhizobia (Bradyrhizobium japonicum) inoculation, individually or in combination. The experimental design was of randomized complete block with four replicates, where the area of each plot was $10.5 \mathrm{~m}^{2}$. The soil samples $(0-30 \mathrm{~cm})$ were taken before the performance of the experiment, where some physical and chemical properties were determined using the standard methods according to Black (1965) and Page et al. (1982).

Rhizobia (Bradyrhizobium japonicum) were provided by biofertilizer production unit, Soils, Water and Environment Research Institute, Agriculture Research Center (ARC), Giza, Egypt. Rhizobium was cultured in yeast mannitol broth medium (Vincent, 1970), incubated at $28^{\circ} \mathrm{C}$ for three days on a rotary shaker until early log phase to ensure population density of $4 \times 10^{9} \mathrm{cfu} /$ $\mathrm{mL}$ culture. Vermiculite supplemented with $10 \%$ Irish peat was packed into polyethylene bags (300 g carrier per bag), then sealed and sterilized with gamma irradiation $\left(5.0 \times 10^{6}\right.$ rads $)$. Rhizobium culture was injected into the carrier to $60 \%$ of the maxima water holding capacity. Rhizobia Egypt. J. Bot. 57, No.1 (2017) 
(Bradyrhizobium japonicum), a N-fixing bacteria, was used as inoculum, where peanut seeds were mixed gently with inoculant at a rate of $300 \mathrm{~g}$ carrier per 60 $\mathrm{kg}$ seed, prior to sowing using arabic gum solution (16\%) as an adhesive agent.

Elemental sulphur was conducted as $15 \mathrm{Kg}$ S/fed., $30 \mathrm{Kg}$ S/fed and $45 \mathrm{Kg}$ $\mathrm{S} / \mathrm{fed}$, singly or in combination with Rhizobia (Bradyrhizobium japonicum) inoculation. As sulphur metal is insoluble in water, so, after application, it should be intensively incorporated into soil, where it is oxidized by soil microorganisms to form $\mathrm{SO}_{4}{ }^{2-}$ to be available for plants (Stroehlein and Pennington, 1986).

All plots received basal doses of phosphorus fertilizer during soil tillage before peanut seeds sowing, at the rate of $30 \mathrm{Kg} \mathrm{P}_{2} \mathrm{O}_{5} / \mathrm{fed}$ as calcium superphosphate $\left(15 \% \quad \mathrm{P}_{2} \mathrm{O}_{5}\right)$. The potassium fertilizer was added at the rate of $48 \mathrm{~kg} / \mathrm{fed}$ as potassium sulphate $\left(48 \% \mathrm{~K}_{2} \mathrm{O}\right)$, as recommended dose after 35 days from sowing. All tested treatments received $30 \mathrm{Kg} \mathrm{N} / \mathrm{fed}$ in the form of ammonium nitrate $(33.5 \% \mathrm{~N})$ in two equal doses, one after thinning and the other after one month from sowing.

Seeds of peanut (Arachis hypogaea L) cultivar were provided by Field Crops Research Institute, ARC, Giza, Egypt. Seeds of peanut were inoculated as investigated above and planted on 4 and $9^{\text {th }}$ of May for the first and second agricultural seasons, respectively, at a rate $60 \mathrm{Kg} / \mathrm{fed}$. Two seeds were in hill and $20 \mathrm{~cm}$ spacing, after emergency, plants were thinned to one plant per hill. Other field practices were followed in the usual manner for peanut cultivation. Plants were grown till maturity and harvested. The area of each sample was 1 $\mathrm{m}^{2}$. The harvest dates were on 6 and $9^{\text {th }}$ of September for the first and second seasons, respectively. At harvest (120 days after sowing), agronomic trials were as follows: 100-seeds weight, Pods yield, seeds yield, straw yield and shilling $\%$.

\section{Methods of analyses}

For chemical determinations, plants were fine powdered after harvest; wet digestion for dry material was carried out according to Chpman and Pratt (1961). Nitrogen percentage was determined in peanut seeds by micro Kjeldal method and Seed crude protein percentage was calculated by multiplying N\% by 6.25 as described by AOAC (1990). Phosphorus and potassium percentages were estimated in peanut seeds according to AOAC (1990). Oil percentage in seeds was determined by Soxlit apparatus and petroleum ether as an organic solvent as described by AOAC (1990). The atomic absorption spectrophotometer was used to determine $\mathrm{Zn}, \mathrm{Mn}, \mathrm{Fe}$, and $\mathrm{Cu}$ in seeds according to the method described by AOAC (1990).

\section{Nodulation status, total bacterial counts and activities of some enzymes}

After 50 and 80 days from sowing, four plants and their surrounded soil rhizosphere were selected randomly from each treatment and used to determine the following parameters:- Nodulation status and nitrogenase enzyme: Nodules were separated carefully from roots of each plant, counted and weighed, Egypt. J. Bot. 57, No.1 (2017) 
g/plant; used for nitrogenase $\left(\mathrm{N}_{2}\right.$-ase) assay, then dried and weighed. Nitrogenase enzyme $\left(\mathrm{N}_{2}\right.$-ase $)$ activity of nodules was assayed by the acetylene reduction assay (Hardy et al., 1973). Total bacterial counts were determined in peanut rhizosphere soil according to Holm and Jenson (1972) by plate count technique using soil extract agar medium. Dehydrogenase (DHA) enzyme activity of rhizosphere plants was also determined by the method described by Casida et al. (1964). $\mathrm{CO}_{2}$ evolution in peanut rhizosphere soil was estimated according to Allen (1959).

All data obtained were statistically analyzed according to Gomez and Gomez (1984).

\section{Results and Discussion}

The data obtained was mean of both growth seasons.

\section{General view on the experimental soil}

Initial state of the experimental soil is shown in Table 1, which indicates that sandy soil is characterized by sandy textural grade, with a low content of organic matter and low SP\%. The available macro- and micronutrient contents of soil under consideration are lower than the critical limits. Accordingly, the studied soil is suffering from deficient in plant nutrients.

TABLE 1. Physical and chemical properties of the experimental soil.

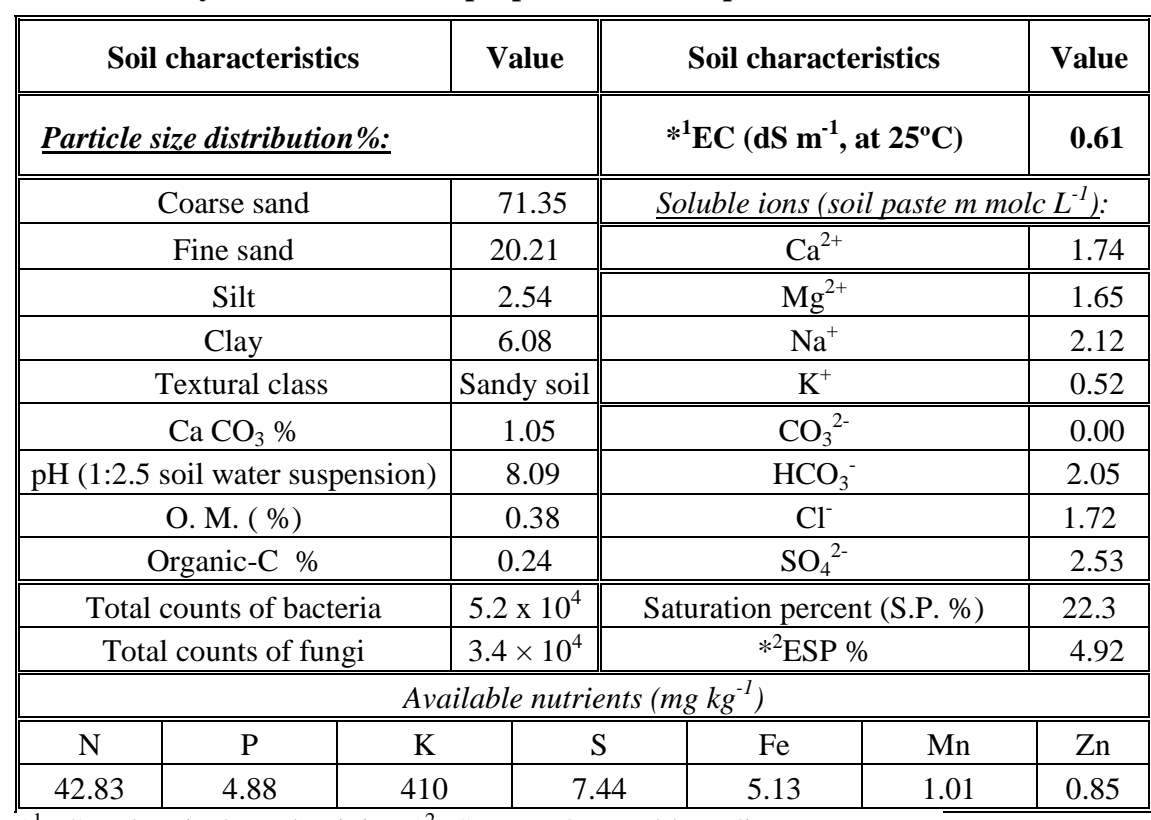

${ }^{* 1}$ EC:- Electrical conductivity, ${ }^{2}$ ESP:- Exchangeable sodium percentage. 
Response of some soil properties and available nutrients to the applied treatments

A. Some soil properties

In respective of elemental sulphur, data in Table 2 showed a clearly response of some soil properties, i.e., $\mathrm{pH}, \mathrm{EC}$ (Electrical conductivity) and ESP (Exchangeable sodium percentage) to the applied treatments, particularly those treated with the highest rates of elemental sulphur of 30 or $45 \mathrm{~kg} \mathrm{fed}^{-1}$, with insignificant differences. That was true, since elemental sulphur can oxidized by many soil microorganisms forming sulphuric acid, leading to frequent reactions with chemical compounds resulting from the microbial activity of Rhizobia (Bradyrhizobium japonicum) itself, consequently such acidic media led to lowering soil $\mathrm{pH}$ value. Also, the created sulphuric acid reacts with the native soil $\mathrm{CaCO}_{3}$ and resulting in $\mathrm{CaSO}_{4}$. The latter can be ionized to $\mathrm{Ca}^{2+}$ and $\mathrm{SO}_{4}{ }^{2-}$, which was also reduced soil $\mathrm{pH}$. These results are in agreement with those obtained by (Awadalla et al., 2003).

TABLE 2. Effect of sulphur and Rhizobia inoculation on ameliorating some soil properties.

\begin{tabular}{|c|c|c|c|c|}
\hline \multirow[b]{2}{*}{ Treatments } & \multirow{2}{*}{$\begin{array}{c}\text { Sulphur rate } \\
\text { (Kg/fed) }\end{array}$} & \multicolumn{3}{|c|}{ Soil properties } \\
\hline & & pH & $\begin{array}{c}E C \\
\left(d^{\prime} \mathrm{m}^{-1}\right)\end{array}$ & $\begin{array}{c}\text { ESP } \\
\%\end{array}$ \\
\hline \multirow{4}{*}{ UnInocutation } & Control & 8.22 & 5.34 & 15.45 \\
\hline & 15 & 7.85 & 5.04 & 14.05 \\
\hline & 30 & 7.34 & 4.56 & 11.00 \\
\hline & 45 & 7.32 & 4.51 & 10.80 \\
\hline \multirow{4}{*}{ Inocutation } & Control & 8.20 & 5.21 & 15.22 \\
\hline & 15 & 7.78 & 4.56 & 11.52 \\
\hline & 30 & 7.25 & 3.60 & 10.70 \\
\hline & 45 & 7.21 & 3.41 & 9.30 \\
\hline \multicolumn{2}{|c|}{ LSD at 0.05} & --- & 0.45 & 1.32 \\
\hline
\end{tabular}

${ }^{* 1}$ EC:- Electrical conductivity, ${ }^{2}$ ESP:- Exchangeable sodium percentage.

On the other hand, the released soluble ions of $\mathrm{Ca}^{2+}$ can be improved soil aggregation, due to a $\mathrm{Ca}^{2+}$ partial substitution by exchangeable $\mathrm{Na}^{+}$that enhancing the coagulation of $\mathrm{Na}$-separated clay particles and leading to reduce ESP value, which encouraging the formation of small clay domains. Such clay domains are coated with soil humified organic substances, and then forming coarse pores that are increased soil permeability and accelerating leaching of a pronounced content of excess soluble salts, and then reducing EC value. The effective role of microbial activity in combination with applied elemental sulphur for ameliorating soil properties could be interpreted according to many opinion outlined by Bacilio et al. (2003), Shaban and Omar (2006) and Ashmay et al. (2008) who reported that, rhizobial strains produce several phytohormones (i.e., indole acetic acid and cytokinins) and organic acid. Such products simultaneously improving soil structure, i.e., increasing aggregate stability and drainable pores. Consequently, these created conductive pores enhancing the leaching process of soluble salts through irrigation fraction.

Egypt. J. Bot. 57, No.1 (2017) 


\section{B. Soil available nutrients}

In general, the obtained data presented in Table 3 showed that, the beneficial effect of the applied treatments, particularly elemental sulphur at the applied rates of 30 or $45 \mathrm{~kg} \mathrm{fed}^{-1}$, with insignificant differences. That was commonly achieved by lowering soil $\mathrm{pH}$ and in turn encouraging the availability of plant essential nutrients, especially phosphorus and sulphur as macronutrients as well as $\mathrm{Fe}, \mathrm{Mn}, \mathrm{Zn}$ and $\mathrm{Cu}$ as micronutrients.

The superiority of combined effect of added elemental sulphur as soil application and bio-fertilizer as Rhizobia (Bradyrhizobium japonicum) for the noticeable increment in soil available nutrient contents could be attributed to the pronounced decreases in the values of soil $\mathrm{pH}$, EC and ESP vs the favorable amelioration in soil biological conditions that encouraging the released nutrients from soil native sources in the available forms, as well as easier mobility towards plant roots, and in turn their uptake by plants. In addition, the application of elemental sulphur tend to accelerate the released active inorganic acid $\left(\mathrm{H}_{2} \mathrm{SO}_{4}\right)$ that leads to controlling soil availability and mobility of nutrients, which are more sensitive to the undesirable effects of alkaline soil media. Consequently, the applied elemental sulphur to the soil plays an important role for its nutritional status, whether be under demand as strategic storehouse for unavailable native nutrients. In this connection, Mohammed, (2004) interpreted the integrated role of applied elemental sulphur plus bio-fertilizer (Rhizobia), which resulted in more pronounced nutrients availability in the soil, on the basis of lowering soil $\mathrm{pH}$ and microbial activity that enhances the solubilization of nutrient from the native and added sources. Moreover, such prevailing conditions enhance the slow release of nutrients during the mineralization processes as well as minimizing their possible lose by leaching. These finding are also in agreement with Kaplan et al. (2005), who reported that, a potential strategy to enhance nutrients availability is the lowering soil $\mathrm{pH}$ that can be achieved through application of acid-producing fertilizers like sulphure-containing materials.

TABLE 3. Effect of sulphur and Rhizobia inoculation on soil availability of some nutrient contents.

\begin{tabular}{|c|c|c|c|c|c|c|c|c|c|}
\hline \multirow{3}{*}{ Treatments } & \multirow{3}{*}{$\begin{array}{c}\text { Sulphur } \\
\text { rate } \\
\text { (Kg/fed) }\end{array}$} & \multicolumn{8}{|c|}{ Soil available nutrient content $\left(\mathrm{mg} \mathrm{kg}^{-1}\right.$ soil) } \\
\hline & & \multicolumn{4}{|c|}{ Macronutrients } & \multicolumn{4}{|c|}{ Micronutrients } \\
\hline & & $\mathrm{N}$ & $\mathrm{P}$ & $\mathrm{K}$ & $\mathrm{S}$ & $\mathrm{Fe}$ & Mn & $\mathrm{Zn}$ & $\mathrm{Cu}$ \\
\hline \multirow{4}{*}{$\begin{array}{c}\text { UnInocutatio } \\
\mathrm{n}\end{array}$} & Control & 35.61 & 3.59 & 191.1 & 6.73 & 3.93 & 0.98 & 0.82 & 0.47 \\
\hline & 15 & 41.95 & 4.13 & 201.4 & 8.58 & 4.50 & 1.34 & 1.09 & 0.70 \\
\hline & 30 & 46.10 & 4.47 & 207.0 & 10.85 & 4.78 & 1.61 & 1.23 & 0.81 \\
\hline & 45 & 47.15 & 4.77 & 209.2 & 10.98 & 5.95 & 1.66 & 1.29 & 0.85 \\
\hline \multirow{4}{*}{ Inocutation } & Control & 37.18 & 5.98 & 199.4 & 8.02 & 4.75 & 1.10 & 1.01 & 0.76 \\
\hline & 15 & 56.19 & 6.74 & 223.3 & 9.34 & 6.13 & 1.34 & 1.44 & 1.17 \\
\hline & 30 & 65.54 & 7.53 & 236.9 & 12.76 & 7.00 & 2.49 & 1.79 & 1.47 \\
\hline & 45 & 66.19 & 8.19 & 241.7 & 12.93 & 7.13 & 2.61 & 1.92 & 1.56 \\
\hline \multicolumn{2}{|c|}{ LSD at 0.05} & 2.11 & 0.98 & 5.80 & 0.45 & 0.23 & 0.11 & 0.05 & 0.04 \\
\hline
\end{tabular}

Egypt. J. Bot. 57, No.1 (2017) 


\section{C- Yield and yield components}

Data in Table 4 showed that, using any rate of sulphur fertilizer have an alleviating effect on deleterious effect caused by nutrients deficiency, resulting in a significant increase in yield and yield components of peanut.

TABLE 4. Effect of sulphur and Rhizobia inoculation on yield and yield components of peanut plant.

\begin{tabular}{|c|c|c|c|c|c|c|}
\hline Treatments & $\begin{array}{c}\text { Sulphur } \\
\text { rate } \\
(\mathbf{K g} / \mathbf{f e d})\end{array}$ & $\begin{array}{c}\mathbf{1 0 0 - s e e d} \\
\text { weight } \\
(\mathbf{g})\end{array}$ & $\begin{array}{c}\text { Pods } \\
\text { yield }(\mathbf{K g} / \\
\mathbf{f e d})\end{array}$ & $\begin{array}{c}\text { Seed yield } \\
(\mathbf{K g} / \mathbf{f e d})\end{array}$ & $\begin{array}{c}\text { Straw } \\
\text { yield } \\
(\mathbf{K g} / \mathbf{f e d})\end{array}$ & $\begin{array}{c}\text { Shilling } \\
(\boldsymbol{\%})\end{array}$ \\
\hline \multirow{4}{*}{ Uninoculation } & Control & 74.40 & 1375 & 928 & 1710 & 63.06 \\
\cline { 2 - 7 } & 15 & 77.15 & 1469 & 991 & 1837 & 65.34 \\
\cline { 2 - 7 } & 30 & 78.63 & 1496 & 1013 & 1888 & 66.69 \\
\cline { 2 - 7 } & 45 & 80.70 & 1520 & 1032 & 1858 & 67.58 \\
\hline \multirow{5}{*}{ Inoclatation } & Control & 81.27 & 1546 & 1063 & 1990 & 64.44 \\
\cline { 2 - 7 } & 15 & 85.44 & 1571 & 1100 & 2009 & 66.11 \\
\cline { 2 - 7 } & 30 & 88.45 & 1603 & 1136 & 2038 & 67.12 \\
\cline { 2 - 7 } & 45 & 90.71 & 1611 & 1161 & 2065 & 68.34 \\
\hline \multicolumn{2}{|c|}{ LSD at 0.05} & 1.43 & 78.05 & 41.07 & 81.35 & 1.44 \\
\hline
\end{tabular}

The rate of $45 \mathrm{Kg}$ S/fed was the most effective one, where the relative increases in 100-seed weights and pods yield reached 8.47, likewise, 8.60 compared to the control. The positive effect of sulphur as a fertilizer, may be due to lowering soil $\mathrm{pH}$ and increasing nutrients availability through its oxidation by soil microorganisms to sulphuric acid or sulphate rises and exerts a positive effective on soil characters (Table 1), which reflected on the crop yield and its biochemical characters (El-Hamzawi, 2001, Azer et al., 2003 and Nassar, 2007). Sharma and Gupta (1991) found that, the increases in biomass yield with higher S doses may be due to the positive response of plant to applied $S$, which promotes vegetative growth, starch and seed formation. Also, the increased supply of photosynthates to peanut pods would likely provide an opportunity for seeds to grow to their full size with an obvious increase in seed yield. The results are in accordance with those obtained by Ahmed et al. (2011).

Data of Table 4 cleared that, Rhizobium inoculation resulted in further promotion of the estimated parameters for both growing seasons as compared with the control, since the percentage of increases in seed and straw yield rose to $14.55 \%$ compared to control treatment. In this respect, Sprent and Faria (1988) revealed that, Rhizobium is a major group of heterotrophic $\mathrm{N}_{2}$-fixing organism which invades roots of legumes. Ishac (1988) found that, Rhizobium leguminosarum had the effect of fixing nitrogen with leguminous plants. Abdel-Aziz et al. (1989) ascribed such effect to $\mathrm{N}_{2}$-fixation and production of growth promoting substances. Similar results were obtained by Habib et al. (2010).

Egypt. J. Bot. 57, No.1 (2017) 
It could be concluded from data of Table 4 that, Rhizobia inoculation even singly took an action and gave the highest yield and its attributes, when it combined with sulphur, the yield was magnified till $45 \mathrm{Kg} \mathrm{S} / \mathrm{fed}$, the yield and its attributes were significantly surpassed. This was true for both growing seasons. These results were agreed with those obtained by Abd EL-Fattah and Arisha (2000), who attributes the positive response of plants to the favorable effect of Rhizobia on plant growth, nitrogen fixation, number of pods/plant and seed yield.

In fact, plant growth promoting rhizobacteria have been shown to greatly improve the productivity and quality of many legumes, when they inoculated with rhizobia (Mekhemar et al., 2007; Abdel-Wahab et al., 2008; Kandil et al., 2008; Dileep-Kumar et al., 2001; Vessey and Buss, 2002). Rhizobacteria produced a lot of promoter substances such as auxin, vitamins B group and flavonoids like substances resulting in promotion of initiation and performance of nodulation as well as creation of more infection sites on the hairs and epidermis (Parmar and Dadarwal, 1999; Gage and Margolin, 2000 and Verma et al., 2010).

\section{Nutritional status \\ Macronutrients content and uptake}

The presented data in Table 5 showed that, amendment of soil with $\mathrm{S}$ with different rates owing to a significant improvement in macronutrients concentration and uptake in peanut seeds throughout the two growing seasons, as compared with the control treatment. However, dose of $45 \mathrm{Kg} \mathrm{S} / \mathrm{fed}$ exceeded the other doses in ameliorating the deleterious effect of nutrients deficiency on the concentrations and uptake of essential elements in peanut tissues, grown under such severe conditions. The relative increases in $\mathrm{N}$ concentrations and uptake reached $15.67 \%$ compared to control treatment. The positive effect of $\mathrm{S}$ may be due to decreasing soil $\mathrm{pH}$ and increased nutrients uptake and availability to experimental plant (Azer et al., 2003; Cui and Wang, 2005).

Dealing with rhizobia inoculation, it led to significant increases in $\mathrm{P}$ concentrations and uptake in seeds by $22.19 \%$ compared to control. Also, similar trends were found for $\mathrm{N} \& \mathrm{P}$ concentrations and uptake in peanut seeds for both growing seasons. In this context, Dashti et al. (1997) suggested that, the promoting mechanism of growth and nitrogen fixing bacteria included direct and indirect effects; the direct one, include an increase in the mobilization of insoluble nutrients followed by enhancement uptake by the plants, production of plant growth regulators and stimulants for plant growth and development; the indirect effect includes positive effect on symbiotic nitrogen fixation by improvement of root nodule number and mass. These results confirmed with (Mohamed et al., 2001 Atta et al., 2003 and Monged et al., 2004).

Egypt. J. Bot. 57, No.1 (2017) 
TABLE 5. Effect of sulphur and Rhizobia inoculation on macronutrient content and uptake of peanut seeds.

\begin{tabular}{|c|c|c|c|c|c|c|c|}
\hline \multirow[b]{2}{*}{ Treatments } & \multirow{2}{*}{$\begin{array}{l}\text { Sulphur } \\
\text { rate } \\
\text { (Kg/fed) }\end{array}$} & \multicolumn{2}{|c|}{$\mathbf{N}$} & \multicolumn{2}{|c|}{$\mathbf{P}$} & \multicolumn{2}{|c|}{$\mathbf{K}$} \\
\hline & & $\begin{array}{c}\text { Content } \\
(\%)\end{array}$ & $\begin{array}{c}\text { Uptake } \\
\text { (Kg/fed) }\end{array}$ & $\begin{array}{c}\text { Content } \\
(\%)\end{array}$ & $\begin{array}{c}\text { Uptake } \\
\text { (Kg/fed) }\end{array}$ & $\begin{array}{c}\text { Content } \\
(\%)\end{array}$ & $\begin{array}{c}\text { Uptake } \\
\text { (Kg/fed) }\end{array}$ \\
\hline \multirow{4}{*}{ Uninoculation } & Control & 3.83 & 35.54 & 0.392 & 3.64 & 0.71 & 6.59 \\
\hline & 15 & 4.16 & 41.23 & 0.428 & 4.24 & 0.78 & 7.73 \\
\hline & 30 & 4.27 & 43.26 & 0.440 & 4.46 & 0.85 & 8.61 \\
\hline & 45 & 4.43 & 45.72 & 0.467 & 4.82 & 0.89 & 9.18 \\
\hline \multirow{4}{*}{ Inoclatation } & Control & 4.49 & 47.73 & 0.479 & 5.10 & 0.90 & 9.57 \\
\hline & 15 & 4.62 & 50.82 & 0.492 & 5.41 & 0.95 & 10.45 \\
\hline & 30 & 4.74 & 53.85 & 0.513 & 5.83 & 0.96 & 10.91 \\
\hline & 45 & 4.86 & 56.42 & 0.526 & 6.11 & 0.98 & 11.38 \\
\hline \multicolumn{2}{|c|}{ LSD at 0.05} & 0.17 & 3.22 & 0.02 & 0.39 & 0.03 & 0.71 \\
\hline
\end{tabular}

With respect to interaction between rhizobia inoculation and sulphur supplements, statistical analysis clarified high significant increase for N, P and $\mathrm{K}$ concentrations and uptake in seeds in both growing seasons. The highest impact was inducted under rhizobia inoculation $+45 \mathrm{Kg}$ S/fed addition, since the relative increase in $\mathrm{K}$ concentrations rose to $38.03 \%$ compared to control treatment. The positive impacts of sulphur may be due to improving soil physical and chemical properties conducted with improvement biological characters and fertility status via rhizobia inoculation. Both complementary actions led to enhancement the availability of most essential nutrients in soil, the plant will accumulate more nutrients to reach the balance between cations and anions, which push the plant to give higher dry matter and longer roots enable more absorption levels, assimilation rates and biochemical processes in whole plant organs (Marchner, 1998).

\section{Micronutrients content and uptake}

Data in Table 6 declared that, adding sulphur to soil significantly increased micronutrients content and uptake in seeds in both growing seasons as compared without sulphur application. Application $45 \mathrm{Kg} \mathrm{S} /$ fed was the most effective rate than others, where the percentage of increases in $\mathrm{Fe}$ and $\mathrm{Zn}$ were 15.68 and $19.91 \%$, respectively. That sulphur application rate was produced significant increases for Fe \& Zn uptake by about 28.65 and 32.24\%, respectively.

Effect of elemental sulphur on the availability of micronutrients was studied by many investigators. They explained the indirect effect of sulphur in soil by its conversion to sulphuric, which has a solvent action for several important micronutrients (Makary, 2002). Yousry et al. (1984) found that, DTPA extractable Fe and Mn increased after applying Sulphur. Abd El-Fattah and Hilal (1985) reported that, use of sulphur as soil amendment would in case of $\mathrm{Fe}, \mathrm{Mn}, \mathrm{Zn}$ and $\mathrm{Cu}$ deficient soil, increase the availability of those nutrients and evoke a plant response.

Egypt. J. Bot. 57, No.1 (2017) 
TABLE 6. Effect of sulphur and Rhizobia inoculation on micronutrient contents and uptake of peanut seeds.

\begin{tabular}{|c|c|c|c|c|c|c|c|c|c|}
\hline \multirow{2}{*}{ Treatments } & \multirow{2}{*}{$\begin{array}{l}\text { Sulphur } \\
\text { rate } \\
\text { (Kg/fed) }\end{array}$} & \multicolumn{2}{|c|}{$\mathbf{F e}$} & \multicolumn{2}{|c|}{ Zn } & \multicolumn{2}{|c|}{ Mn } & \multicolumn{2}{|c|}{$\mathrm{Cu}$} \\
\hline & & $\begin{array}{c}\text { Content } \\
(\%)\end{array}$ & $\begin{array}{c}\text { Uptake } \\
\text { (Kg/fed) }\end{array}$ & $\begin{array}{c}\text { Content } \\
(\%)\end{array}$ & $\begin{array}{c}\text { Uptake } \\
\text { (Kg/fed) }\end{array}$ & $\begin{array}{c}\text { Content } \\
(\%)\end{array}$ & $\begin{array}{l}\text { Uuptake } \\
\text { (Kg/fed) }\end{array}$ & $\begin{array}{c}\text { Content } \\
(\%)\end{array}$ & $\begin{array}{c}\text { Uptake } \\
\text { (Kg/fed) }\end{array}$ \\
\hline \multirow{4}{*}{ Uninoculation } & Control & 252.16 & 234.00 & 68.31 & 63.39 & 73.14 & 67.87 & 10.25 & 9.51 \\
\hline & 15 & 265.96 & 263.56 & 74.15 & 76.48 & 80.12 & 79.40 & 10.91 & 10.81 \\
\hline & 30 & 277.93 & 281.54 & 77.63 & 78.64 & 84.59 & 85.69 & 11.56 & 11.71 \\
\hline & 45 & 291.70 & 301.03 & 81.23 & 83.83 & 88.41 & 91.24 & 11.92 & 12.30 \\
\hline \multirow{4}{*}{ Inoclatation } & Control & 297.27 & 316.00 & 82.66 & 87.87 & 91.38 & 97.14 & 12.15 & 12.92 \\
\hline & 15 & 306.27 & 336.90 & 87.15 & 95.87 & 94.03 & 103.43 & 12.35 & 13.59 \\
\hline & 30 & 316.84 & 359.93 & 89.88 & 102.10 & 96.38 & 109.49 & 12.67 & 14.50 \\
\hline & 45 & 330.19 & 383.35 & 92.14 & 106.87 & 98.64 & 114.52 & 13.29 & 15.43 \\
\hline \multicolumn{2}{|c|}{ LSD at 0.05} & 9.02 & 18.57 & 3.80 & 6.26 & 4.23 & 7.34 & 0.40 & 0.75 \\
\hline
\end{tabular}

Regarding rhizobial inoculation of peanut seeds, results in Table 6 showed a pronounced significant increase in micronutrients content and its uptake in seeds for the two growing seasons. The relative increases in Mn content and uptake was $24.94 \%$ as compared to control. These results are in harmony with those of (Atta et al., 2003; Monged et al., 2004). Furthermore, the highest content and uptake in peanut seeds were inducted when Rhizobium inoculation was associated with sulphur, especially at $45 \mathrm{Kg} \mathrm{S} / \mathrm{fed}$ for both growing seasons. The relative increase for $\mathrm{Cu}$ content was $29.66 \%$ as compared to control.

Bio-chemical components of peanut seeds

Results at Table 7 revealed that, crude protein, protein yield, oil percent and oil yield were significantly increases due to sulphur application rate up to 45 $\mathrm{Kg} \mathrm{S} / \mathrm{fed}$, since the relative increases in crude protein and protein yield reached to $15.66 \%$ as compared to $\mathrm{S}$-free application. The positive role of sulphur fertilizer might be due to the fact that, sulphur is an integral part of sulphurcontaining amino acids (cystein, cytstine and methionine), hence, improved protein as well as oil synthesis in peanut seeds (Tamak et al., 1997). Likewise, sulphur is usually required by legumes and is called a master nutrient for oil and seed production (Nassar, 2007 and Salimpour et al., 2012). Sulfur is absorbed by plants roots from soil as sulfate and transported as a phosphate ester. Sulfate is reduced to sulfide via sulfite before it is incorporated into cysteine and other organo-sulfur compounds. $\mathrm{SO}_{4}{ }^{2-} \rightarrow \mathrm{SO}_{3}{ }^{2-} \rightarrow \mathrm{H}_{2} \mathrm{~S} \rightarrow$ cysteine $\rightarrow$ methionine (Pronk et al., 1990). Ligha and Giri (1999) reported that, increases in oil content by sulphur application might be attributed to involvement of sulphur in the biosynthesis of oil. The higher oil yield by sulphur addition was obviously because of higher seed yield and oil content. 
TABLE 7. Effect of sulphur and Rhizobia inoculation on crude protein, protein yield, oil\% and oil yield of peanut seeds.

\begin{tabular}{|c|c|c|c|c|c|}
\hline Treatments & $\begin{array}{c}\text { Sulphur rate } \\
\text { (Kg/fed) }\end{array}$ & $\begin{array}{c}\text { Crude } \\
\text { Protein \% }\end{array}$ & $\begin{array}{c}\text { Protein } \\
\text { yield } \\
\text { (Kg/fed.) }\end{array}$ & Oil \% & $\begin{array}{r}\text { Oil yield } \\
\text { (Kg/fed.) }\end{array}$ \\
\hline \multirow{4}{*}{ Uninoculation } & Control & 23.94 & 222.16 & 44.11 & 409.34 \\
\hline & 15 & 26.00 & 257.66 & 46.14 & 457.25 \\
\hline & 30 & 26.69 & 270.37 & 47.31 & 479.25 \\
\hline & 45 & 27.69 & 285.76 & 49.22 & 507.95 \\
\hline \multirow{4}{*}{ Inoclatation } & Control & 28.06 & 298.28 & 50.12 & 532.78 \\
\hline & 15 & 28.88 & 317.68 & 51.22 & 563.42 \\
\hline & 30 & 29.63 & 336.60 & 53.44 & 607.08 \\
\hline & 45 & 30.38 & 352.71 & 55.22 & 641.10 \\
\hline \multicolumn{2}{|c|}{ LSD at 0.05} & 1.32 & 19.48 & 1.28 & 29.01 \\
\hline
\end{tabular}

Similarly, Rhizobium inoculation produced significant improvement in the estimated parameters for both growing seasons, where the relative increases in oil percent reached $13.63 \%$ as compared to control. Concerning the combined treatment with sulphur, data showed that, motivation of Rhizobium was highly pronounced, when combined with S fertilizer at rate of 15,30 and $45 \mathrm{Kg}$ S/fed. The application of Rhizobium accompanied with $45 \mathrm{Kg}$ S/fed gave the highest significant increases in all studied parameters, since the relative increases in oil yield rose to 56.62 and $57.87 \%$, at the first and second season, respectively. Regarding to $\mathrm{N}$-fixing bacteria, the important nitrogenase enzymes contains an $\mathrm{Fe}-\mathrm{Mo}-\mathrm{S}$ cluster, is a catalyst that performs the important function of nitrogen fixation, converting atmospheric nitrogen to ammonia that can be used by microorganisms and plants to synthesize proteins, DNA, RNA, alkaloids, and the other organic nitrogen compounds necessary for plant life (Lippard and Berg, 1994). The yield, quality and uptake of nutrients by black gram improved favorably with increasing levels of $\mathrm{S}$ as well as in combination with Rhizobium, this significant increase in these parameters might be due to better nutritional environment due to Rhizobium and $S$ application. Since $S$ is essential for $\mathrm{S}$ containing amino acids and plays a vital role in regulating the metabolic and enzymatic process including photosynthesis, respiration and symbiotic $\mathrm{N}$ fixation. Whereas the positive effect of Rhizobium might be due to its beneficial effect on $\mathrm{N}$ fixation and better root development (Kumar and Singh, 2009; Singh et al., 2005).

The improvement in plant growth and nutrient uptake upon rhizobial inoculation may be attributed to the several mechanisms such as biological nitrogen fixation (Chanway and Holl, 1991), synthesis of siderophores, compounds that chelate iron from soil, making it available to the plant, (Kloepper et al., 1986 and Verma et al., 2010), solubilizing minerals, or synthesis of plant hormones, such as auxins or gibberellins, (Probanza et al.,

Egypt. J. Bot. 57, No.1 (2017) 
2001) or plant hormone regulators, such as 1-aminocycloprophane-1carbxylate deaminase (Glick, 1995 and Glick et al., 1995), an enzyme that decrease endogenous concentrations of ethylene and disease suppression and their coordinated expression were responsible in enhancing plant growth, and nutrient uptake of legumes (Dey et al., 2004 and Tilak et al., 2005).

\section{F- Nodulation status and nitrogenase $\left(\mathrm{N}_{2}\right.$-ase) activity}

Effect of sulphur application and Rhizobia (Bradyrhizobium japonicum) individually or in combination as a bio-fertilizer and their impact on nodulation status; number of nodules and its dry weights (mg) per peanut plant and nitrogenase $\left(\mathrm{N}_{2}\right.$-ase) activity after 50 and 80 days of sowing were showed in Table 8.

TABLE 8. Effect of applied sulphur and Rhizobia inoculation on nodulation status and nitrogenase $\left(\mathrm{N}_{2}\right.$-ase $)$ activity in nodules of peanut roots after 50 and 80 days of sowing.

\begin{tabular}{|c|c|c|c|c|c|c|c|}
\hline \multirow{3}{*}{ Treatment } & \multirow{3}{*}{$\begin{array}{l}\text { Sulphur } \\
\text { rate } \\
\text { (Kg/fed) }\end{array}$} & \multicolumn{4}{|c|}{ Nodulation status } & \multirow{2}{*}{\multicolumn{2}{|c|}{$\begin{array}{l}\text { Nitrogenase assay } \\
\text { (n mole } \mathrm{C}_{2} \mathrm{H}_{4} \mathrm{~g} \mathrm{dry}^{-1} \\
\text { nodules }^{-1} \mathrm{hr}^{-1} \text { ) }\end{array}$}} \\
\hline & & \multicolumn{2}{|c|}{$\begin{array}{c}\text { Number of nodules } \\
\left(\text { Plant }^{-1}\right)\end{array}$} & \multicolumn{2}{|c|}{$\begin{array}{c}\text { Dry weight of } \\
\text { nodules }\left(\mathrm{mg} \mathrm{Plant}^{-1}\right)\end{array}$} & & \\
\hline & & $\begin{array}{l}\text { After } 50 \\
\text { days }\end{array}$ & $\begin{array}{l}\text { After } 80 \\
\text { days }\end{array}$ & $\begin{array}{l}\text { After } 50 \\
\text { days }\end{array}$ & $\begin{array}{l}\text { After } \\
80 \text { days }\end{array}$ & $\begin{array}{l}\text { After } 50 \\
\text { days }\end{array}$ & $\begin{array}{c}\text { After } 80 \\
\text { days }\end{array}$ \\
\hline \multirow{4}{*}{$\begin{array}{l}\text { Uninoculat } \\
\quad \text { ion }\end{array}$} & Control & 79 & 107 & 114 & 326 & 138 & 1033 \\
\hline & 15 & 88 & 121 & 167 & 388 & 376 & 1128 \\
\hline & 30 & 98 & 134 & 228 & 427 & 593 & 1232 \\
\hline & 45 & 109 & 156 & 289 & 499 & 723 & 1408 \\
\hline \multirow{4}{*}{$\begin{array}{c}\text { Inoclatatio } \\
\mathrm{n}\end{array}$} & Control & 77 & 105 & 110 & 320 & 141 & 1028 \\
\hline & 15 & 93 & 138 & 201 & 403 & 479 & 1296 \\
\hline & 30 & 112 & 149 & 276 & 509 & 697 & 1497 \\
\hline & 45 & 126 & 171 & 301 & 524 & 771 & 1581 \\
\hline \multicolumn{2}{|c|}{ LSD at 0.05} & 1.21 & 1.82 & 3.08 & 4.63 & 4.893 & 6.109 \\
\hline
\end{tabular}

Rhizobia inoculation improved nodules number and its weighed /plant as well as $\mathrm{N}_{2}$-ase activity of peanut roots, also enhanced total bacterial counts and dehydrogenase enzyme activity in peanut rhizosphere soil after 50 and 80 days from planting under field conditions compared to uninoculated peanut. These results are in accordance with Massoud et al. (2008) who stated that, inoculation with rhizobia induced significant increases in number of nodules/plant, dry weight of nodules/ plant and nitrogenase activity after 75 days from sowing. Also, Akhtar and Siddiqui (2009) showed that, inoculation of Rhizobium prompted significant increases in growth, yield and the number of nodules per root system compared to control plants. The recorded results due to uninoculated plants were acceptable even they were lower than the other inoculated treatments. This behavior could be due to the positive role of native bacteria among several decades ago (Radwan et al., 2007).

Egypt. J. Bot. 57, No.1 (2017) 


\section{G-Biological activity of soil}

Effect of sulphur application and Rhizobia (Bradyrhizobium japonicum) individually or in combination as a biofertilizer and their influence on soil biological activities after 50 and 80 days of sowing were showed in Table 9. Data obtained revealed that, sulphur application and Rhizobia resulted in significant enhancements of dehydrogenase, $\mathrm{CO}_{2}$ evolution and total bacterial counts over control. The influence of dual application $(45 \mathrm{Kg} \mathrm{S} / \mathrm{fed} \mathrm{+}$ Rhizobia) was significantly higher over single $\mathrm{S}$ application at the same level. These results was in harmony with those obtained by Mahmoud et al. (2007) who reported that, Rhizobia (Bradyrhizobium japonicum) combined with organic amendments have more response and enhanced the soil biological activity in terms of increasing total bacterial and cyanobacterial (S. platensis) counts, $\mathrm{CO}_{2}$ evolution, dehydrogenase and nitrogenase activity. It was also reported that, bacteria can be incorporated into soil as organic matter and also as a source of enzymes as they produce extracellular acid and alkaline phosphatases that are active in solution or located in the periplasmatic space of the cell wall. Both biomass exopolysacchraides incorporated into soil, induced a growth promotion of other microorganisms and increased the activity of soil enzymes that participate in the liberation on nutrients required by plants (Caire et al., 2000).

TABLE 9. Effect of applied sulphur and Rhizobia inoculation on the biological activity of soil cultivated by peanut after 50 and 80 days of sowing.

\begin{tabular}{|c|c|c|c|c|c|c|c|}
\hline \multirow{3}{*}{ Treatment } & \multirow{3}{*}{$\begin{array}{l}\text { Sulphur } \\
\text { rate } \\
(\text { Kg/fed })\end{array}$} & \multicolumn{6}{|c|}{ Biological activity of soil } \\
\hline & & \multicolumn{2}{|c|}{$\begin{array}{c}\text { Dehydrogenase } \\
\left(\mu \text { TPF g dry soil }^{-1}\right. \\
\left.\text { day }^{-1}\right)\end{array}$} & \multicolumn{2}{|c|}{$\begin{array}{c}\mathrm{CO}_{2} \text { evolution } \\
\left(\mathrm{mg} 100 \text { g soil }^{-1}\right. \\
\left.\text { day }^{-1}\right)\end{array}$} & \multicolumn{2}{|c|}{$\begin{array}{l}\text { Total bacterial counts } \\
\quad\left(10^{4} \text { cfu } \text { soil }^{-1}\right)\end{array}$} \\
\hline & & $\begin{array}{l}\text { After } 50 \\
\text { days }\end{array}$ & $\begin{array}{c}\text { After } 80 \\
\text { days }\end{array}$ & $\begin{array}{c}\text { After } \\
50 \text { days }\end{array}$ & $\begin{array}{c}\text { After } 80 \\
\text { days }\end{array}$ & $\begin{array}{c}\text { After } 50 \\
\text { days }\end{array}$ & $\begin{array}{c}\text { After } 80 \\
\text { days }\end{array}$ \\
\hline \multirow[t]{4}{*}{ Uninoculation } & Control & 13.5 & 18.4 & 8.98 & 12.80 & 2.5 & 2.40 \\
\hline & 15 & 50.6 & 69.9 & 11.03 & 14.76 & 2.9 & 2.80 \\
\hline & 30 & 77.5 & 87.7 & 12.89 & 17.66 & 3.1 & 3.07 \\
\hline & 45 & 92.6 & 105.5 & 14.37 & 19.60 & 3.8 & 3.60 \\
\hline \multirow[t]{4}{*}{ Inoclatation } & Control & 15.8 & 20.6 & 9.07 & 12.89 & 2.6 & 2.50 \\
\hline & 15 & 82.6 & 104.7 & 19.12 & 21.70 & 40.00 & 38.50 \\
\hline & 30 & 99.4 & 122.2 & 21.03 & 22.57 & 66.00 & 65.00 \\
\hline & 45 & 146.3 & 176.7 & 22.81 & 24.38 & 90.00 & 89.10 \\
\hline \multicolumn{2}{|c|}{ LSD at 0.05} & 3.85 & 4.24 & 2.07 & 1.89 & 1.64 & 1.61 \\
\hline
\end{tabular}

The current data was in agreement with the findings of Laloknam et al. (2006), who reported that, organisms that thrive in hyper saline environments possess specific mechanisms to adjust their internal osmotic pressure. Soil salinity, one of the major abiotic stresses reducing agricultural productivity, Egypt. J. Bot. 57, No.1 (2017) 
affects large terrestrial areas of the world; application of recent developed functional tools for the development of salt-tolerant crops is recommended (Yamaguchi and Blumwald, 2005). One such mechanism is the use of Rhizobia (Bradyrhizobium japonicum), which has the ability to accumulate compatible low-molecular weight organic solutes such as glycine and betaine (Kempf and Bremer, 1998).

Root activity and microbial metabolism may serve as sources of $\mathrm{CO}_{2}$ in soil, the $\mathrm{pH}$ value of such soil will be low and the soil becomes acidic. Besides, $\mathrm{NH} 4^{+}$could be created as a result of $\mathrm{N}$-fixing Rhizobia; it undergoes biological transformation in the soil and form acid forming nitrate ions. Similarly, sulphur also produces acid forming sulphate ions through oxidation. Also, ammonium sulphate could be produced in rhizisphere, ultimately low $\mathrm{pH}$. The increased concentration of $\mathrm{CO}_{2}$, hydrolysis of acid salts and various organic acids increased the total acidity of soil. During organic matter decomposition, humus, organic acids and different acid slats may also be produced. Grover et al. (2015) demonstrates that $\mathrm{CO}_{2}$ influence the richness, composition and structure of soil microbial community and the influence is more on active microbial communities and in the vicinity of roots. High $\mathrm{C}$ : $\mathrm{N}$ ratio under $\mathrm{CO}_{2}$ favors nutrient acquisition ability and biological nitrogen fixers.

Sellamuthu and Govindawamy, (2003) reported that bacterial, fungal and actinomycetes population were increased with application of bio-organics and influenced the dehydrogenese activity. The increase in population may be due to presence of humic acid in root zone, which favors the microbial growth in the rhizosphere. The principal direct effects exhibited by humic onto living organisms include an increase in biomass accumulation, nutrient uptake, biosynthesis, antiviral activity (Cacco et al., 2000). The indirect effects are mostly provided by the bio-organic release from organic compounds driven changes in environmental conditions such as bioavailability of some nutrients salts balance, physical, chemical soil properties such as structure of soil, aeration, drainage, water retaining capacity and soil temperature (Hopkins and Stark, 2003). Abou-Zeid and Bakry, (2011) concluded that, bacterial inoculation, generally, enhanced the soil biological activity in terms of increasing microbial counts, $\mathrm{CO}_{2}$ evolution, dehydrogenase and nitrogenase enzyme activities. This increase of the soil biological activity increased the soil fertility, in turn that is reflected positively on the crop production. These increases may attribute to the $\mathrm{N}_{2}$-fixing bacteria inoculation promote microbial activity of all another microbes in rhizosphere zone and consequently increased biological activity in soil (Tantawi, 2006). Inoculation of peanut seeds with Rhizobium improved nodulation status (Nodules number and dry weight/plant), nitrogenase $\left(\mathrm{N}_{2}\right.$-ase) activity of peanut roots and enhanced microbial counts and dehydrogenase (DHA) enzyme activity in rhizosphere soil of peanut after 50 and 80 days from planting compared to the untreated control (Khalifa et al., 2013).

Egypt. J. Bot. 57, No.1 (2017) 


\section{Conclusion}

It could be concluded that, in newly reclaimed sandy soil, the combined treatment of $45 \mathrm{~kg} \mathrm{~S} / \mathrm{fed}$.+Rhizobium (Bradyrhizobium japonicum) inoculation (300 g carrier per $60 \mathrm{~kg}$ seed; with bacterial population density of $4 \times 10^{9} \mathrm{cfu} /$ $\mathrm{mL}$ culture) was the optimal treatment and effective strategy for improving peanut (Arachis hypogaea L, cv. Giza 5) yield and its components. Data indicated that the individual and combined treatments of Rhizobium and sulphur showed a positive role on soil characteristics, i.e., $\mathrm{pH}, \mathrm{EC}, \mathrm{ESP}$ and available nutrient contents (N, P, K, Fe, Mn and $\mathrm{Zn}$ ) were increased with increasing the applied Rhizobium and sulphur rate. Also, joint application of Rhizobium and sulphur resulted in maximum values of soil biological parameters followed by the individual treatments of Rhizobium and sulphur, respectively. The enhancements of dehydrogenase, nitrogenase, $\mathrm{CO}_{2}$ evolution and total bacterial counts over control were relatively higher in all treatments, especially that of rhizobial inoculation. This may be due to, addition of sulphur to soil fertilized by the recommended doses of NPK causes a series of chemical transformations leads to accumulation of organic matter, that alleviates soil characters favor rhizobium growth and activity, which in turn, owe to optimal nitrogen fixation and production of huge beneficial compounds favors total microbial counts and bioactivities, which reflected positively on peanut crop, resulting in significant increases in its yield, yield components and its chemical composition. Finally, reflected positively on biological activities of the treated soil and improvement the quality and quantity of peanut crop.

Recommendation: Application of the dual treatment of $45 \mathrm{~kg} \mathrm{~S} / \mathrm{fed}+$ Rhizobium (Bradyrhizobium japonicum) inoculation (300 g carrier per $60 \mathrm{~kg}$ seed; with bacterial population density of $4 \times 10^{9} \mathrm{cfu} / \mathrm{mL}$ culture) was the optimal treatment and effective strategy for improving peanut (Giza 5) yield and its components in newly reclaimed sandy soil at Egypt, considering the recommended doses of NPK and the usual recommended practices of peanut.

\section{References}

AOAC (1990) "Association of Official Methods of Analytical Chemists". Official Methods of Analysis $5^{\text {th }}$ ed. Washington. DC, USA.

Abdel-Aziz, R.A., Ishac. Z.Y. and Abdel-Malek, S.M. (1989) Preliminary studies on the effect of inoculation with rhizobacteria on the growth of wheat. Egypt J. Appli Sci., $1(1), 1-9$.

Abdel-Fattah, A. and Hilal, M.H. (1985) Effect of sulphur application on some properties of Egyptian desert soils. Proc. $2^{\text {nd }}$ Arab Regional Conf. on sulphur and its usages. 1,39-53.

Abdel-Fattah, H.I. and Arisha, H.M. (2000) Effect of Rhizobium inoculation and vitamin $\mathrm{B}_{12}$ on growth, yield and quality of common bean under sandy soil conditions. Zagazig J, Agric. Res., 27(1), 59-70.

Egypt. J. Bot. 57, No.1 (2017) 
Abdel-Maksoud, M.F. (2008) Response of two peanut cultivars to row width and hill spaces in sandy soil. Research of Agriculture and Biological Science 4 (5), 447-454.

Abdel-Wahab, A.F.M., Mekhemar, G.A.A., Badawi, F.Sh.F. and Heba, Sh. Shehata (2008) Enhancement of nitrogen fixation, growth and productivity of Rhizobium-lupin symbiosis via co-inoculation with rhizobacteria in different soil types. J. Agric. Sci. 33, 469-484. (Mansoura University, Egypt).

Abou-Zeid, M.Y. and Bakry, M.A.A. (2011) Integrated effect of bio-organic manures and mineral frtilizers on potato productivity and the fertility status of a calcareous soil. Australian. J. Basic and Appl Scie 5(8), 1385-1399.

Ahmed, G., Jan, A., Arif, M., Jan, M.T. and Shah, H. (2011) Effect of nitrogen and sulphur fertilization on yield components, seed and oil yield of canola. J. Plant Nutri 34 (14), 2069-2082.

Ahmad, A. and Abdin, M.Z. (2000) Photosynthesis and its related physiological variables in the leaves of Brassica genotypes as influenced by sulphur fertilization. Physiologia Plantarum, 110 (1), 144-149.

Akhtar, M.S. and Siddiqui, Z.A. (2009) Use of plant growth-promoting rhizobacteria for the biocontrol of root-rot disease complex of chickpea. Aust. Plant Pathol. 38(1), 44-50.

Allen, O.M. (1959) "Experiments in Soil Bacteriology”, $1^{\mathrm{St}}$. ed. Burgess Publisher Company. Minnesota, USA.

Ashmay, S.H., Shaban, Kh. A. and Abd El-Hader, M.G. (2008) Effect of mineral nitrogen, sulphur, organic and bio-fertilizers on maiz productivity in saline soil of Sahl El-Tina. Minufia J. Agric. Res., 33(1),195-209.

Atta, M.I., Abdel-Hameed, A.M. and Nasef, M.A. (2003) Effect of some micronutrients as foliar application and Rhizobium inoculation on growth, yield and its components and nutrients uptake by faba bean. J. Product \& Dev 2, 389-405.

Awadalla, A.A., Salib, M.M. and Ibrahim, S.B. (2003) Response of maiz yield grown on calcareous soil to some organic and inorganic amendments under irrigation with saline drainage water. Egypt J. Appl Sci., 18(1), 366-381.

Azer Sohair, A., Awad, A.M., Jacklin, G.S., Khalil, F.A. and EL-Aggory, E.M. (2003) A comparative study on the effect of elemental S and biophsphatic fertilizers on the response of faba bean (Vicia faba L.) to P fertilization. Egypt J. Appli Sci .,18 (7), 324-363.

Bacilio, M., Vazquez, P. and Bashan, Y. (2003) Alleviation of noxious effects of cattle ranch composts on wheat seed germination by inoculation with Azospirillum spp. Biol . Fertil. Soils, 38, 261-266.

Badawi, F. Sh. F., Biomy, A.M.M. and Desoky, A.H. (2011) Peanut plant growth and yield as influenced by co-inoculation with Bradyrhizobium and some rhizomicroorganims under sandy loam soil conditions. Annals Agric. Sci., 56, 1-9. (Fac Agric Ain Shams University, Egypt).

Egypt. J. Bot. 57, No.1 (2017) 
Black, C.A. (1965) "Methods of Soil Analysis". Amer Society of Agronomy. Madison, Washington, USA.

Blake-Kalff, M.M.A. (2000) Diagnosing sulfur deficiency in field-grown oilseed rape (Brassica napus L.) and wheat ( Triticum aestivum L.). Plant and Soil, 225 (1/2), 95-107.

Cacco, G., Attina, E., Gelsomino, A. and Sidari, A. (2000) Effect of nitrate and humic substance of different molecular size on kinetic parameters of nitrate uptake in wheat seedlings. J. plant Nutr Soil Sci., 163, 313-320.

Caire, G., Storni de Cano, M.M., Palma, R.M. and Zaccaro, M.C. (2000) Changes in soil enzyme activity by cyanobacterial biomass and exopolysacchride. Soil Biol Biochem., 32, 65-76.

Casida, L.E., Klein, D.A. and Santoro, T. (1964) Soil dehydrogenase activity. Soil Sci. 98, 371-376.

Ceccotti, S.P. (1996) Plant nutrient sulphur-a review of nutrient balance, environmental impact and fertilizers. Fertilizer Research, 43 (1-3), 117-125.

Chanway, C.P. and Holl, F.B. (1991) Biomass increase and associative nitrogen fixation of mycrrorhizal Pinus contorta seedlings inoculated with a plant growth promoting Bacillus strain. Can J. Bot., 69, 507-511.

Chapman, H.O. and Pratt, P.E. (1961) "Methods of Analysis for Soil and Plant and Water". Univ. of California Agric Sci, Precede publication 3034: 50, California, USA.

Cui, Y. and Wang, Q. (2005) Interaction of zinc and elemental sulphur on their uptake by spring wheat. J. Plant Nutri., 28, 639-649.

Dashti, N., Zang, F., Hynes, R. and Smith, D.L. (1997) Application of plant growth promoting rhizobacteria to soybean (Glycine $\max$ L.) increase protein and dry matter yield under short season conditions. Plant and Soil, 188, 33-41.

Dey, R., Pal, K.K., Bhatt, D.M. and Chauhan, S.M. (2004) Growth promotion and yield enhancement of peanut (Arachis hypogaea L.) by application of growthpromoting rhizobacteria. Microbiol. Res., 159, 371-394.

Dileep-Kumar, B.S., Berggren, I. and Martensson, A.M. (2001) Potential for improving pea production by co-inoculation with fluorescens Pseudomonas and Rhizobium. Plant and Soil 229, 25-34.

EL-Hamzawi Dalia, A.S. (2001) Biochemical studies on some nutrients effect on plant. Ph.D. Dissertation, Cairo University, Egypt.

EL-Saadany, S.M. and Abd EL-Rasoul, Sh,M. (1999) Effect of Gypsum, FYM and phsphorin application on peanut crop grown on newly reclaimed sandy soil. Egypt J. Appli Sci., 14 (7), 611-625.

El-Sayed, S.A.M. (2006) Effect of sulphur, phosphorus and molybdenum applications on chemical composition of soybean seeds. J. Adv. Agric. Res ., 11 (2), 259-269.

Egypt. J. Bot. 57, No.1 (2017) 
Gage, D.J. and Margolin, W. (2000) Hanging by a thread: invasion of legume plants by rhizobia. Curr Opinion Microbial 3, 613-617.

Glick, B.R. (1995) The enhancement of plant growth by free-living bacteria. Can J Microbiol., 41,109-117.

Glick, B.R., Karaturovic, D.M. and Newell, P.C. (1995) A novel procedure for rapid isolation of plant growth promoting Pseudomonads. Can J. Microbiol. 41, 533-536.

Gomez, K.A. and Gomez, A.A. (1984) "Statistical Procedure for Agricultural Research", John Wiley \& Sons Inc, New York, USA.

Grover, M., Mandapaka, M., Desai, S., Gopinath, K.A. and Venkateswarlu, B. (2015) Elevated $\mathrm{CO}_{2}$ : Plant associated microorganisms and carbon, App. Soil. Ecology, 95, 73-85.

Habib, F.M., Abdel Hamed, A.H., Ali, A.A. and IL-Sayed, I.F. (2010) Bio and organic fertilization as mean for maximizing the efficiency of mineral fertilizer. An effect on soybean growth and yield. Egypt J. Appli, Sci ., 25 (12A), 825-836.

Hardy, F., Bums, C. and Holston, D. (1973) Application of the acetylene assay for measurement of nitrogen fixation. Soil. Biol. Biochem., 5, 47-81.

Holm, E. and Jenson, V. (1972) Aerobic chemoorganotrophic bacteria of a Danish beach forest. OIKOS 23, 248- 260.

Hopkins, B. and Stark, J. (2003) Humic acid effects on potato response to phosphorus. Presented at the Idaho Potato Conference, January, 22-23.

Ishac, Y.Z. (1988) "Inoculation with Associative $N_{2}$-fixers in Egypt". $4^{\text {th }}$ Inter. Sym. On nitrogen fixation with non-legumes, pp: 241-246.

Kandil, B.A.A., Badawi, F.Sh.F., El-Baz, M.G.M. and Abdel-Wahab, A.F.M. (2008) Response of peanut yield to inoculation with both Rhizobium sp. and silicate bacteria (Bacillus circulans) under graded levels of feldspar amendment. J. Agric. Sci., 33 (6), 4463-4477. (Mansoura University, Egypt).

Kaplan, M., Orman, S., Kader, I. and Koncz, J. (2005) Heavy metal accumulation in calcareous soil and sorghum plants after addition of sulphur-contanting wastes as a soil amendment in Turkey. Agric. Ecosyst, Environ., 111, 41-46.

Kempf, B. and Bremer, E. (1998) Uptake and synthesis of compatible solutes asmicrobial stress responses to high-osmolality environments. Arch. Microbial., 170, 319-330.

Khalifa, M.M.A., Abou-Zeid, M.Y. and Fetyan Nashwa, A.H. (2013) Performance of fungicides application and Rhizobium inoculation for controlling peanut soil born diseases and their effects on nodulation status and some enzyme activities. J. Appl . Scie. Res., 9 (4), 2750-2766.

Kloepper, J.W. (2003) A review of mechanisms for plant growth promotion by PGPR. $6^{\text {th }}$ international PGPR workshop. 6-10 October 2003, Calcutta, India.

Egypt. J. Bot. 57, No.1 (2017) 
Kloepper, J.W., Scher, F.M., Laliberte, M. and Tipping, B. (1986) Emergencepromoting rhizobacteria: description and implications for agriculture. In: "Iron, Siderophres and Plant Disease”; Swinburne, T.R., Ed.; Plenum Publishing Crop. New York, USA.

Kumar, S. and Singh, T.B. (2009) Effect of varying levels of sulphur with and without Rhizobium on yield, quality and nutrient uptake of black gram. An. Asian.J. of Soil . Sci., 4(1), 154-155.

Lalokman, S., Ttanaka, K., Buaboocha, T., Waditee, R., Incharoensakdi, A., Hibino, T., Tanaka, Y. and Takabe, T. (2006) Halotolerant Cyanobacterium Aphanothece halophytica contains a betaine transporter active at alkaline ph and high salinity. Appl. Environ. Microb.72, 6018-6026.

Legha, P.K. and Giri, G. (1999) Influence of nitrogen and sulphur on growth, yield and oil content of sunflower (Helianthus annus) grown in spring season. Indian. J. Agron, 44(2), 408-412.

Lippard, S.J. and Berg, J.M. (1994) "Principles of Bioinorganic Chemistry". University Science Books. Mill Valley, California,USA.

Makary, B.Sh. (2002) Effect of some organic and inorganic fertilizers with sulphur element on yield of corn and its influence on some soil properties. J. Agric. Sci., 27(2), 1301-1313. (Mansura University, Egypt.

Massoud, A.M., Abou-Zeid, M.Y., Hassan, El-Sayeda A. and El-Fiki, S.F. (2008) Influence of phosphate dissolving and nitrogen fixing bacteria on faba bean under different levels of phosphorus fertilization. J Agric Sci., Mansoura Univ., Egypt 33(11), 8137-8153.

Marschner H. (1998) "Mineral Nutrition of Higher Plant”. $2^{\text {nd }}$ Ed. Academic Press. London, UK.

Mekhemar, G.A.A., Shaaban, M., Ragab, A.A. and Biomy, A.M.M. (2005) Response of faba bean to inoculation with Rhizobium leguminossarum bv. viceae and plant growth promoting rhizobacteria under newly reclaimed soils. Egypt $J$. Appl. Sci. 20, 126-144.

Mekhemar, G.A.A., Ismail, F.M., Badawi, F.Sh.F. and Kandil, B.A.A. (2007) Response of Peanut (Arachis hypogaea L.) to co-inoculation with Rhizobium spp. and phosphate dissolving bacteria under different levels of phosphorus fertilization in sandy soils. Agric. Res. J. 7 (1), 1-8. (Suez Canal University, Egypt).

Mohamed, M.R., Abd El-Salam, H.Z. and EL-Saeed, M.A. (2001) Effect of biofertilizer and micronutrients on growth, yield and chemical composition of some broad bean varieties (Vicia faba) in salt affected soils. J. Agric. Sci., 26 (2), 11691176. (Mansoura University, Egypt).

Mohammed, S.S. (2004) Assessment of the relative effectiveness for some organic materials conjucted with mineral nitrogen on soil fertility status, yield and quality of wheat grown on a newly cultivated soil. Egypt. J.Apply. Sci., 19(3), 298-310.

Egypt. J. Bot. 57, No.1 (2017) 
Mahmoud, A.A., Mostafa, A.M. Soha, Abd El-Azz, A. M. and Hegazi, A.Z. (2007) Effect of cyanobacterial inoculatiuon in presence of organic and inorganic amandments on carrot yield and sandy soil properties under drip irrigation regime. Egypt J. of Appl. Sci., 22, 716-733.

Mohsen, S.A.S. and Saeed, N.A. (2005) Effect of mineral nitrogen, farmyard manure and bacterial inoculation on two soybean cultivars. Annals of Agric. Sci., 43 (4), 1391-1399. (Moshtohor, Egypt).

Monged Nadia, O., Allam, S.M., Abd EL-Mabed, A.A. and Abu EL-Fotoh, H.H. (2004) Some nutritional trials to improve the yield and seed quality of soybean plant. Egypt J. Appli. Sci., 19 (1), 330-343.

Nassar, K.E.M. (2007) Response of faba bean and soybean to direct and residual impacts of elemental sulphur and different levels and phosphorus and iron spraying under calcareous soil condition. Minufiya J. Agric. Res. 32 (2), 537-552.

Nassar, K.E.M., Ewais Magda, A. and Mohamed Awatif, A. (2006) Raising of the quantity and quality of onion crop by foliar application of phosphorus and sulphur. $J$ Adv. Agric. Res. 11 (2), 409-419. (Saba Basha Agric Alexandria, Egypt).

Page, A.L., Miller, R.H. and Keeney, D.R. (1982) "Methods of Soil Analysis". Part 2. Chemical and Microbiological Properties pp: 595-624. American Society of Agronomy. Madison, Wisconsin, USA.

Parmar, N. and Dadarwal, K.R. (1999) Stimulation of nitrogen fixation and induction of flavonoid like compounds by rhizobacteria. J. Appl. Microbiol. ,86, 36-44.

Probanza, A., Mateos, J.L., Lucas, J.A., Ramos, B., Felipe, M.R. and Guyierrez, Manero, F.J. (2001) Effects of inoculation with PGPR Bacillus and Pisolithus tinctorius on Pinus pinea L. growth bacterial rhizosphere colonization and mycorrhizal infection. Microbiol. Ecol. , 41(2),141-148.

Pronk, J.T., Meulenberg, R., Hazeu, W., Bos, P. and Kuenen, J.G. (1990) Oxidation of reduced inorganic sulphur compounds by acidophilic thiobacilli . FEMS Microbiology Letters 75 (2-3), 293-306.

Radwan, T.E.E., Hassona, B., El-Khatib Ilham, I. and Kandil, B.A.A. (2007)Impact of nitrogen fixers and phosphate dissolving bacteria on faba bean under the influence of different amounts of phosphorus. Egypt J. Microbiol., 16, 177-190.

Salimpour, S., Khavazi, K., Nadian, H., Besharati, H. and Miransari, M. (2012) Conola oil production and nutrients uptake as affected by phosphate solubilizing and sulphur oxidizing bacteria. J. Plant. Nutri., 35 (13), 1997-2008.

Sellamuthu, K.M. and Govindaswamy, M. (2003) Effect of fertilizer and humic acid on rhizosphere microorganisms and soil enzymes at an early stage of sugarcan growth. Sugar. Tech., 5, 273-277.

Singh, H., Singh, G. and Ajay, K. (2005) Effect of P and S on yield and quality of blackgram. Annals of Plants and Soil, Res. 7 (1), 99-100.

Egypt. J. Bot. 57, No.1 (2017) 
Shaban, Kh.A. and Omar, M.N.A. (2006) Improvement of maize yield and some soil properties by using nitrogen mineral and PGPR group fertilization in newly cultivated saline soils. Egypt J. Soil. Sci ., 46 (3) 329-342.

Sharma, R.A. and Gupta, R.K. (1991) Response of rainfed soybean, sunflower sequence to $\mathrm{N}$ and $\mathrm{S}$ fertilization in black clay soils. J. Indian. Soc. Soil. Sci ., 39, 197-200.

Sprent, J.I. and De Faria, S.M. (1988) Mechanisms of infection of plants by nitrogen fixing organisms. Plant and Soil., 110, 157-165.

Stroehlein, J.L. and Pennington, D.A. (1986) Use of sulphur compounds for soil and irrigation water treatments. In: Tabatabai, M.A. (Ed.) Sulphur in agriculture. Agron. Monogr., 27, 435-454, ASA, CSSA, Madison, USA.

Tamak, T.C., Sharma, H.C. and Singh, K.P. (1997) Effect of phosphorus, sulphur and boron on seed yield and quality of sunflower (Helianthus annus). Indian. J. Agron., 42 (1), 173-176.

Tantawi, A. Eman (2006) Response of maize to Azotobacter and cyanobacteria inoculation under sandy soil condition. Egypt J. of Appl. Sci., 21(5), 359-374.

Tilak, K.V.B.R., Rangamaki, N., Pal. K.K., De, R., Saxena, K.A., Shekhar, Nautiyal, C., Mittal, S., Tripathi, A.K. and Tohri, B.N. (2005) Diversity of plant growth and soil health supporting bacteria. Current Sci., 89, 136-150.

Verma, J.P., Yadav, J., Tiwari, K.N. and Singh, V. (2010) Impact of plant growth promoting rhizobacteria on crop production. Int. J. Agric. Res. 5, 954-983.

Vessey, J.K. and Buss, T.J. (2002) Bacillus cereus UW85 inoculation effects on growth, inoculation and $\mathrm{N}$-accumulation in grain legumes. Controlled environment studies. Can. J. Plant. Sci., 82, 282-290.

Vincent, J.M. (1970) A Manual for the Practical Study of the Root Nodule Bacteria. I B P, Hand book, No. 15, Bluckwell Publishers, Oxford, UK.

Wu, S.C., Cao, Z.H., Li, Z.G., Cheng, K.C. and Wang, M.H. (2005) Effect of biofertilizer contain $\mathrm{N}$-fertilizer, $\mathrm{P}$ and $\mathrm{K}$ solubilizers and $\mathrm{AM}$ fungi on maize growth: A greenhouse trial. Geoderma 12 (1-2),145-155.

Yamaguchi, T. and Blumwald, E. (2005) Developing salt-tolerant crop plants: Challenges and opportunities. Trends plant, Sci., 10, 615-620.

Yousry, M., El-Laboudi, A. and Khater, A. (1984) Effect of sulphur and petroleum by-products on soil characteristics. 1-Availability of certain nutrients in calcareous soil under intermitted leaching. Egypt, J. Soil . Sci., 24, 185-194.

Zaharn, H.H. (1999) Rhizobium-legume symbiosis and nitrogen fixation under severe conditions and in an arid climate. Microbiol. Mol. Bio. Rev. 63 (4), 968-989.

Zhao, F., Hawkesford, M.J. and McGrath, S.P. (1999) Sulphur assimilation and effects on yield and quality of wheat. J. Cereal, Sci., 30 (1), 1-17.

Egypt. J. Bot. 57, No.1 (2017) 
تأثير إضافة الكبريث و التلقيح بالريزوبيا علي محصول وجودة نبات الفول السوداني النامي في الأراضي الرملية الميزي المستصلحة حديثا

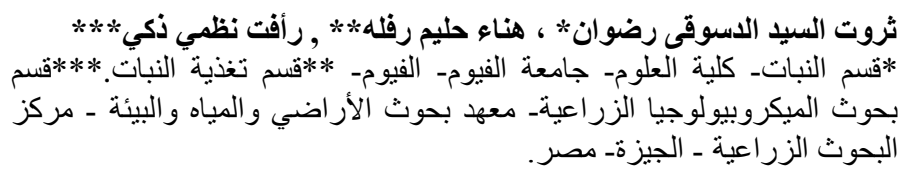

أجريت تجربتان حقليتان في أرض رملية بححطة البحوث الزراعية

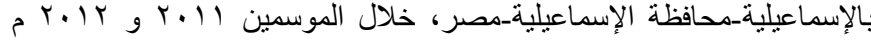

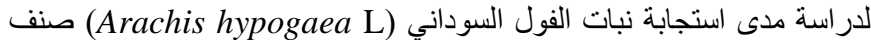

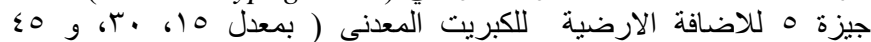

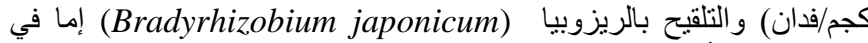

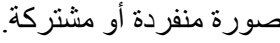

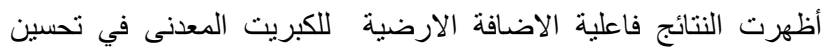

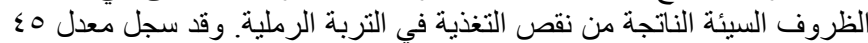

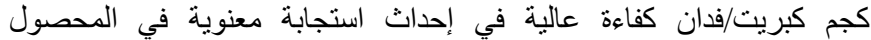

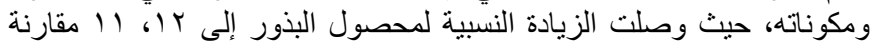

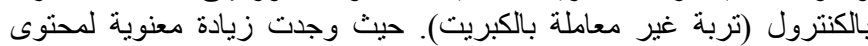

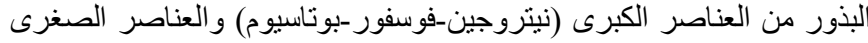

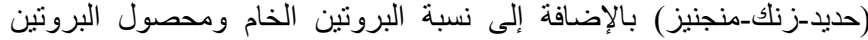

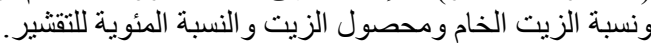

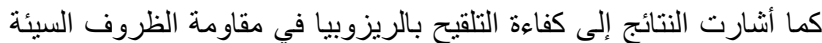

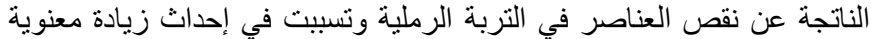

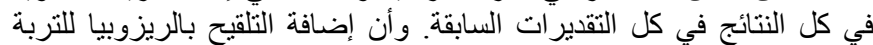

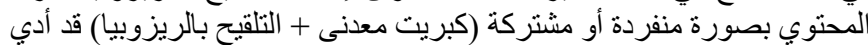

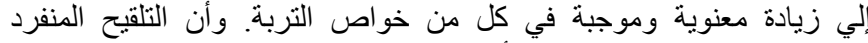

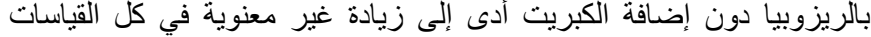

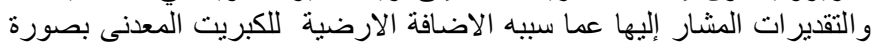

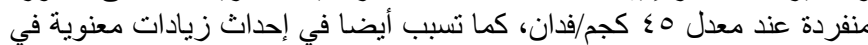

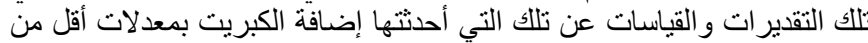

أوضحت نتائج المعاملات المزدوجة أن إضافة الكبريت بالمعدلات المختلفة

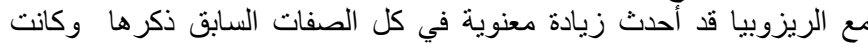

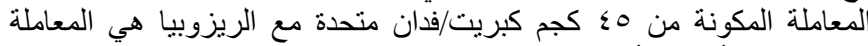

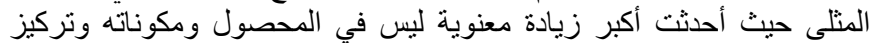

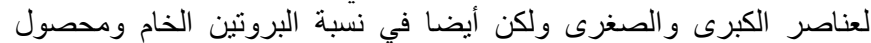

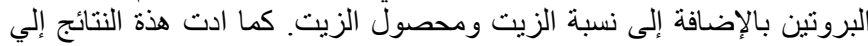

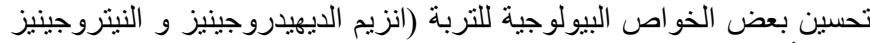

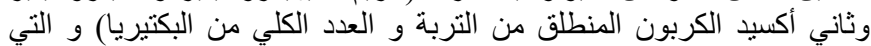

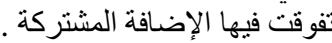


وفى ضوء ما تقدم يوصى البحث باستخدام المعاملة المزدوجة وهي الاضافة

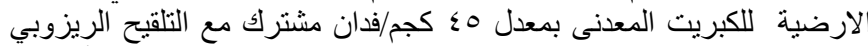

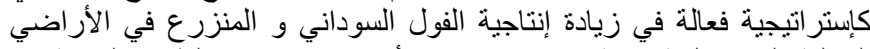

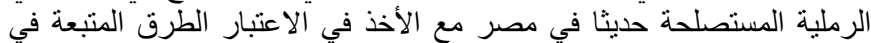

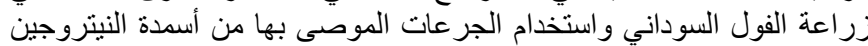
والفوسفور و البوتاسيو م. 